\title{
PERAN KOMITMEN ORGANISASIONAL SEBAGAI VARIABEL MEDIASI PADA PENGARUH STRES KERJA TERHADAP TURNOVER INTENTION KARYAWAN
}

\author{
Anak Agung Bagus Alit Sidi Mantra ${ }^{1}$ \\ Agoes Ganesha Rahyuda ${ }^{2}$
Fakultas Ekonomi Dan Bisnis Universitas Udayana Email : gungalitbk89@gmail.com

\begin{abstract}
ABSTRAK
Tujuan penelitian ini adalah untuk mengetahui peran komitmen organisasional sebagai variabel mediasi pada pengaruh stres kerja terhadap turnover intention karyawan PT. BPR Pedungan. Penelitian ini dilakukan pada karyawan PT. BPR Pedungan, dengan jumlah sampel yang ditentukan melalui teknik sampel jenuh yaitu sebanyak 75 orang karyawan. Data dianalisis menggunakan teknik analisis jalur (path analysis). Pengumpulan data melalui wawancara dan penyebaran kuesioner.Hasil penelitian ini menunjukkan bahwa stres kerja memiliki pengaruh negatif dan signifikan terhadap komitmen organisasional. Stres kerja memiliki pengaruh positif dan signifikan terhadap turnover intention. Komitmen organisasional memiliki pengaruh negatif dan signifikan terhadap turnover intention. Komitmen organisasional secara positif dan signifikan memediasi pengaruh stres kerja terhadap turnover intention karyawan PT. BPR Pedungan.

Kata kunci: stres kerja, komitmen organisasional, turnover intention
\end{abstract}

\begin{abstract}
The purpose of this study was to determine the role of organizational commitment as a mediating variable on the effect of job stress on employee turnover intention at PT. BPR Pedungan. This research was conducted on employees of PT. BPR Pedungan, with a sample size determined through a saturated sample technique, as many as 75 employees. Data were analyzed using path analysis techniques. Collecting data through interviews and distributing questionnaires. The results of this study indicate that job stress has a negative and significant effect on organizational commitment. Job stress has a positive and significant effect on turnover intention. Organizational commitment has a negative and significant effect on turnover intention. Organizational commitment positively and significantly mediates the effect of job stress on employee turnover intention at PT. BPR Pedungan.

Keywords: job stress, organizational commitment, turnover intention
\end{abstract}




\section{PENDAHULUAN}

Berdasarkan Undang-Undang (UU) Perbankan No.7 tahun 1992 sebagaimana yang telah diubah menjadi UU No.10 tahun 1998, bahwa berdasarkan jenis kegiatan usahanya, bank dapat dibagi menjadi dua yaitu Bank Umum dan Bank Perkreditan Rakyat (BPR). Jumlah BPR di Bali saat ini mencapai 137 BPR. Banyaknya jumlah BPR di Bali tentunya akan menimbulkan suatu persaingan yang ketat antar BPR dalam menjalankan usahanya. Untuk mencapai suatu keunggulan kompetitif salah satu hal yang berperan penting adalah pengelolaan sumber daya manusia (SDM). Kunggulan kompetitif dapat diciptakan melalui pengelolaan sumber daya manusia yang efektif (Sandi dkk, 2019).

Dalam perkembangan global saat ini, persoalan tenaga kerja bagi negara maju maupun negara yang sedang berkembang seperti Indonesia cukup menarik perhatian untuk dikaji. Hal itu didasarkan asumsi bahwa tenaga kerja adalah modal dasar dalam proses pembangunan yang menempati posisi paling strategis, sebab sebagai tenaga kerja adalah sumber daya perusahaan yang perlu diperhatikan dalam perkembangan suatu perusahaan. Tenaga kerja yang berhubungan kerja dengan perusahaan, mempunyai peran yang sangat penting bagi kemajuan perusahaan. Dengan demikian, sewajarnyalah apabila kepada mereka diberikan perlindungan, pemeliharaan, dan pengembangan terhadap kesejahteraannya. Menurut Mary (2016) perihal tenaga kerja, perusahaan sebaiknya menjadikan tenaga kerja sebagai salah satu fokus pengembangan dari strategi perusahaan. Hal tersebut dikarenakan perusahaan yang akan berkembang adalah perusahaan yang dapat memaksimalkan potensi tenaga kerjanya.

PT. BPR Pedungan merupakan sebuah perusahaan yang bergerak di bidang perbankan. PT. BPR Pedungan memberikan pelayanan kepada masyarakat dengan menawarkan jasa penghimpunan dana dalam bentuk tabungan dan deposito serta menawarkan dana pinjaman atau kredit bagi pengusaha mikro, kecil, dan menengah. PT. BPR Pedungan merupakan lembaga kuangan pertama yang didirikan di desa Pedungan. PT BPR Pedungan sendiri sudah berdiri sejak tanggal 25 Januari 1970 dengan nama Bank Desa Pedungan, tujuan pembangunan bank ini sendiri adalah untuk membantu mensejahterakan kehidupan ekonomi masyarakat Pedungan yang pada saat itu sedang mengalami krisis ekonomi,oleh karena itu PT. BPR Pedungan memiliki peran yang sangat penting bagi kehidupan ekonomi masyarakt di desa Pedungan dan masih berdiri hingga kini untuk terus membantu menyelesaikan masalah keuangan masyarakat di Desa Pedungan. Dalam menjalankan usahanya dan memberikan kepuasan kepadapara nasabah, PT. BPR Pedungan tentunya sangat membutuhkan karyawan yang berkualitas, kreatif, disiplin, karyawan yang memiliki kemampuan bekerja dengan baik, dan bersedia berkontribusi dalam bentuk apapun untuk memberikan dampak positif bagi perusahaan. PT. BPR Pedungan sendiri memiliki karyawan berjumlah 87 orang. Dimana pada tahun 2017 dan 2019 memiliki tingkat persentase turnover yang cukup tinggi. Berikut data turnover karyawan PT. BPR Pedungan tahun 20162019 (sumber: Profil perusahaan PT. BPR Pedungan). 
Tabel 1.

Data Turnover Karyawan pada PT. BPR Pedungan periode 2016-2019

\begin{tabular}{|c|c|c|c|c|c|c|}
\hline Tahun & $\begin{array}{l}\text { Jumlah } \\
\text { Karyawan } \\
\text { Awal } \\
\text { Periode } \\
\text { (Orang) } \\
\text { (1) }\end{array}$ & $\begin{array}{l}\text { Jumlah } \\
\text { Karyawan } \\
\text { Akhir } \\
\text { Periode } \\
\text { (Orang) } \\
\text { (2) }\end{array}$ & $\begin{array}{l}\text { Rata- } \\
\text { rata } \\
\text { (3) } \\
=\frac{(1)+(2)}{2}\end{array}$ & $\begin{array}{l}\text { Jumlah } \\
\text { Karyawan } \\
\text { Masuk } \\
\text { (Orang) } \\
\text { (4) }\end{array}$ & $\begin{array}{l}\text { Jumlah } \\
\text { Karyawan } \\
\text { Keluar } \\
\text { (Orang) } \\
\text { (5) }\end{array}$ & $\begin{array}{l}\begin{array}{l}\text { Tingkat } \\
\text { Turnover } \\
\text { (\%) }\end{array} \\
(\mathbf{6}) \\
=\frac{(5)}{(3)} \times 100 \%\end{array}$ \\
\hline 2016 & 97 & 103 & 100 & 14 & 8 & $8 \%$ \\
\hline 2017 & 103 & 95 & 99 & 5 & 13 & $13,1 \%$ \\
\hline 2018 & 95 & 92 & 93,5 & 4 & 7 & $7,5 \%$ \\
\hline 2019 & 92 & 87 & 89,5 & 5 & 10 & $11,2 \%$ \\
\hline
\end{tabular}

Sumber:Personalia PT. BPR Pedungan, 2020

Tabel 1. menunjukkan persentase karyawan PT. BPR Pedungan yang mengundurkan diri diatas 10\%, terdapat pada tahun 2017 dengan tingkat turnover sebesar 13,1\% dan pada tahun 2019 dengan tingkat turnover sebesar 11,2\%.

Turnover intention merupakan saat seorang karyawan memiliki kecenderungan untuk berhenti dari pekerjaanya (Robbins dan Judge, 2017). Turnover biasanya merupakan salah satu pilihan terakhir bagi seorang karyawan apabila dia mendapatkan kondisi kerjanya sudah tidak sesuai lagi dengan apa yang diharapkannya. Berdasarkan hasil pra riset terhadap 5 orang karyawan di PT. BPR Pedungan dengan masing-masing jabatan dan status yang berbeda seperti yang disajikan pada Tabel 2.

Tabel 2.

Data Karyawan yang Berkontribusi dalam Pra Riset

\begin{tabular}{lcc}
\hline \multicolumn{1}{c}{ Jabatan } & Status & Keterangan \\
\hline Personalia & Kontrak & Sisa kontrak 8 bulan \\
IT & Tetap & Sudah bekerja selama \pm 2 tahun \\
Admin Kredit & Kontrak & Sisa kontrak \pm 1 tahun \\
Kasir & Kontrak & Sisa kontrak \pm 1 tahun \\
Kolektor Tabungan & Tetap & Sudah bekerja selama \pm 6 \\
& & tahun \\
\hline
\end{tabular}

Sumber: Hasil pra riset terhadap 5 orang karyawan PT. BPR Pedungan, 2020

Menurut pra riset yang menggunakan data dan wawancara terhadap lima karyawan PT. BPR Pedungan, ada indikasi rata-rata tentang keinginan karyawan utntuk meninggalkan perusahaan dikarenakan stres yang disebabkan oleh beban kerja yang berlebihan, kemudian mereka juga merasa tidak sanggup untuk melakukan job rotation yang mengakibatkan para karyawan harus mempelajari hal baru yang dirasa sulit bagi mereka yang akhirnya mengakibatkan stres bagi mereka. Hasil pra riset lainnya adalah dimana 3 dari 5 orang karyawan memiliki tingkat komitmen organisasional yang terbilang cukup rendah, yang bisa dinilai dari respon karyawan yang hanya beranggapan perusahaan hanya tempat bekerja dan yang terpenting mereka mendapatkan gaji atas pekerjaannya tanpa adanya indikasi rasa bangga menjadi bagian dari perusahaan.

Salah satu bentuk perilaku karyawan yang sering muncul akibat kegagalan perusahaan mengelola SDM yang dimilikinya adalah keinginan untuk berpindah kerja (turnover intention) yang mengakibatkan keputusan karyawan untuk 
meninggalkan pekerjaannya. Bramantara dan Dewi (2015) menyebutkan turnover intention adalah kadar atau intensitas dari keinginan karyawan untuk keluar dari perusahaan. Azeez et al (2016) menyatakan bahwa tingginya tingkat turnover akan mengurangi efisiensi dan produktivitas perusahaan, sebaliknya jika tingkat turnover rendah maka efisiensi dan produktifitas perusahaan akan terjaga. Tingginya tingkat turnover perusahaan akan berdampak bagi pendapatan perusahaan karena turnover menimbulkan biaya perekrutan, biaya pelatihan, dan biaya yang dikeluarkan untuk mengisi posisi yang kosong di dalam perusahaan (Ariansyah, 2019). Penyebab terjadinya turnover antara lain stress kerja, kepuasan kerja, komitmen organisasional, lingkungan kerja, dan lain sebagainya (Lestari dan Mujiati, 2018). Setiyanto dan Hidayati (2017) menyatakan bahwa turnover intention dipengaruhi oleh kepuasan kerja dan komitmen organisasional.

Salah satu faktor yang dapat mempengaruhi turnover intention adalah stres kerja. Siddiqui dan Jamil (2015) menunjukkan bahwa stres kerja merupakan salah satu faktor utama yang mempengaruhi turnover intention karyawan. Beban kerja yang semakin berat, persaingan yang semakin ketat, banyaknya kebutuhan yang ingin dipenuhi, tingkat pendapatan tak sejalan dengan biaya hidup adalah masalah yang sering dihadapi karyawan. Karyawan sering kali dihadapkan dengan berbagai macam masalah di dalam maupun di luar perusahaan sehingga sangat mungkin bagi mereka untuk terkena stres. Stres yang berlebihan tidak mampu ditolelir karena individu tersebut kehilangan kemampuan untuk mengendalikan dirinya secara utuh. Akibatnya mereka tidak dapat lagi mengambil keputusan keputusan secara tepat dan perilakunya menjadi terganggu. Dampak lain yang terjadi adalah sakit secara fisik, putus asa, sering absen dan lain - lain. Selama tingkat stres belum teratasi, maka tingkat produktivitas/prestasi kerja cendrung menurun drastis. Stres merupakan isu utama yang menjadi perhatian karena telah menjadi bagian dari kehidupan karyawan dan sulit untuk menghindari stres dalam pekerjaan (Parvaiz et al., 2015).

Hasil penelitian Yuda dan Ardana (2017) mengemukakan bahwa stres kerja memiliki pengaruh positif terhadap turnover intention. Penelitian Siddiqui dan Jamil (2015) menunjukkan bahwa terdapat hubungan positif dan langsung antara stres kerja dan turnover intention, sehingga peningkatan stres kerja akan meningkatkan pula keinginan berpindah kerja. Sewandi dan Perere (2016) menyatakan bahwa stres kerja berpengaruh positif terhadap turnover intention. Nasution (2017) juga mengungkapkan bahwa stres kerja memiliki pengaruh signifikan dan positif pada turnover intention. Ketabchi dan Hazraty (2015) membuktikan bahwa stres kerja mempunyai pengaruh positif terhadap turnover intention, semakin tinggi stres kerja pada karyawan maka turnover intention karyawan akan semakin tinggi juga.

Faktor lain yang mempengaruhi turnover intention adalah komitmen organisasional. Komitmen organisasional menunjukan bagaimana kesediaan karyawan melanjutkan pekerjaannya, setia kepada organisasinya, menerapkan usaha ekstra untuk pencapaian tujuan dan pengidentifikasian karyawan dalam memenuhi tujuan organisasi (Meriani dan Sudibya, 2016). Pristiwati dan Sunuharyo (2018) komitmen organisasional sebagai sebuah sikap mengenai loyalitas karyawan kepada organisasi dan merupakan sebuah proses bagi anggota 
organisasi untuk memberikan perhatian kepada organisasi yang akan menghasilkan keberhasilan bagi organisasi tersebut di masa yang akan datang. Rendahnya komitmen orgaisasional akan berpengaruh terhadap kepuasan kerja dan turnover intention karyawan. Maka dari itu komitmen organisasional yang baik sangat dibutuhkan guna mencapai tujuan organisasi.

Thakre (2015) yang meneliti mengenai hubungan komitmen organisasional terhadap turnover intention menemukan bahwa adanya hubungan negatif antara turnover intention dengan komitmen organisasional, dimana terdapat indikasi turnover intention yang tinggi menandakan komitmen yang rendah. Kalidass dan Bahron (2015) juga menyatakan bahwa komitmen organisasional berhubungan negatif terhadap turnover intention. Susilo dan Satrya (2019) menyatakan bahwa komitmen organisasional berpengaruh negatif dan signifikan terhadap turnover intention. Youcef et al. (2016) memperlihatkan komitmen organisasional memiliki perngaruh yang negatif dan signifikan terhadap turnover intention. Semakin tinggi komitmen organisasional, maka keinginan keluar akan semakin turun. Bhatti et al. (2016) menyatakan bahwa terdapat pengaruh negatif antara komitmen organisasional terhadap turnover intention. Abdurrahim dkk. (2017) menyatakan bahwa komitmen organisasional berpengaruh negatif terhadap turnover intention.

Turnover intention merupakan keinginan seseorang untuk berpindah, belum sampai pada tahap realisasi yaitu melakukan perpindahan dari satu tempat kerja ke tempat kerja lainnya (Putra dan Rahyuda, 2016). Firdaus (2017) turnover intention adalah keinginan untuk berpindah, belum sampai pada tahap realisasi yaitu melakukan perpindahan dari satu tempat kerja ke tempat kerja lainnya.

Turnover Intention timbul dari niat yang mengacu pada aktivitas karyawan untuk meninggalkan perusahaan dan mencari alternatif pekerjaan yang lain (Faslah dan Hariah 2017). Ksama dan Wibawa (2016) turnover intention merupakan masalah yang sering timbul pada sebuahorganisasi yang menyangkut keinginan keluarnya karyawan dalam sebuah organisasi.

Rekha dan Paramanandam (2017) menyatakan bahwa stres adalah suatu kondisi yang terjadi ketika seseorang menyadari tekanan pada diri mereka atau tuntutan situasi yang berada di luar kendali mereka dan jika tuntutan ini terlalu tinggi dan berlanjut dengan jangka waktu yang lama tanpa interval, maka dapat menyebabkan gangguan mental, fisik atau perilaku pada individu tersebut. Syahronica et al. (2015) menyatakan bahwa stres kerja merupakan suatu keadaan yang mempengaruhi emosi, proses berpikir, dan kondisi seseorang seperti kondisi tegang. Beloor et al. (2017) menyatakan bahwa pekerjaan harusdipelihara secara efektif untuk memastikan bahwa semua karyawan bekerja pada potensinya masing-masing dan bebas dari stres.

Stres kerja yang dialami oleh karyawan dapat menimbulkan dampak positif, sekaligus dampak negatif bagi yang bersangkutan dan bagi organisasi atau perusahaan. Aspek positif dari stres kerja itu dapat ditemukan jika dilihat dari kegunaannya dan kesediaan kita dalam menggunakannya. Dari beberapa penjelasan bahwa stres kerja dapat dikemukakan sebagai suatu keadaan tegang yang dialami seseorang didalam suatu organisasi. 
Menurut Jamadin et al. (2015) menyatakan bahwa ketidakmampuan seeorang untuk mengatasi suatu tekanan dalm pekerjaannya dapat dikatakan sebagai stres. Dari pendapat dari beberapa ahli dapat disimpulkan bahwa stress kerja merupakan situasi di mana karyawan merasa tertekan akibat dari pekerjaan ataupun lingkungan di dalam organisasi. Chia-Hao dan Ting-ya (2018) menyatakan bahwa stres kerja adalah keadaan seseorang yang terkena dampak tuntutan, ancaman, pembatasan dan peluang lingkungan kerja, menghasilkan persepsi subjektif dengan pengaruh karakteristik pribadi atau proses mental, dan setelah membandingkan persepsi subjektif dan karakteristik pribadi tersebut, ketidaksetaraan terjadidan menyebabkan keadaan fisik, mental dan stabilitas individu menjadi terganggu.

Kemudian pengaruh stres kerja terhadap komitmen organisasional, yang dimana sudah banyak peneliti yang melakukan penelitian terhadap variabel tersebut diantaranya. Irwanto dkk. (2016) mengungkapkan hal yang sama yaitu stres kerja berpengaruh negatif dan signifikan terhadap komitmen organisasional. Stres kerja berpengaruh negatif pada komitmen organisasi karena semakin tinggi stres mengakibatkan semakin menurunnya komitmen organisasi (Iresa dkk., 2015). Penelitian yang dilakukan oleh Cha et al. (2016) dalam penelitiannya mengungkapkan stres erja memiliki hubungan yang negatif dan signifikan dengan komitmen organisasional. Penelitian dari Harun et al. (2017) juga menunjukkan hasil yang sama yaitu stres kerja memiliki hubungan negatif yang signifikan dengan komitmen organisasional.

Kemudian ada beberapa penelitian yang menemukan bahwa adanya peran komitmen organisasional sebagai variabel mediasi dari pengaruh stres kerja terhadap turnover intention. Irwanto dkk. (2016) menyatakan bahwa komitmen organisasional adalah yang memediasi diantara stres kerja terhadap turnover intention. Putra dan Ardana (2018) komitmen organisasional terbukti memediasi pengaruh antara stres kerja dengan turnover intention secara parsial. Menurut Pranata dan Netra (2019) komitmen organisasional mampu memediasi pengaruh stres kerja terhadap turnover intention.

Stres kerja memiliki pengaruh positif terhadap turnover intention, dimana pengaruh positif mengisyaratkan apabila stres kerja yang dialami oleh karyawan meningkat, maka turnover intention karyawan juga meningkat. Berbagai penelitian telah dilakukan mengenai hubungan antara stres kerja terhadap turnover intention misalnya, penelitian yang dilakukan Yuda dan Ardana (2017) menyebutkan bahwa stres kerja memiliki pengaruh positif terhadap turnover intention. Penelitian Siddiqui dan Jamil (2015) menunjukkan bahwa terdapat hubungan positif dan langsung antara stres kerja dan turnover intention, sehingga peningkatan stres kerja akan meningkatkan pula keinginan berpindah kerja.

Sewandi dan Perere (2016) menyatakan bahwa stres kerja berpengaruh positif terhadap turnover intention. Nasution (2017) juga mengungkapkan bahwa stres kerja memiliki pengaruh signifikan dan positif pada turnover intention. Ketabchi dan Hazraty (2015) juga membuktikan bahwa stres kerja mempunyai pengaruh positif terhadap turnover intention. Pengaruh yang positif mengindikasian dengan semakin tingginya stres kerja yang dirasakan karyawan, 
maka semakin meningkatkan kecenderungan karyawan untuk melakukan turnover. Maka dari itu hipotesis pertama dari penelitian ini adalah:

$\mathrm{H}_{1}$ : Stres Kerja berpengaruh positif dan signifikan terhadap Turnover Intention.

Stres kerja memiliki pengaruh negatif terhadap komitmen organisasional yang dimana jika stres kerja seorang karyawan tinggi maka karyawan tersebut akan memiliki komitmen organisasional yang rendah. Berbagai penelitian telah dilakukan mengenai hubungan antara stres kerja terhadap komitmen organisasional, dimana diantaranya dilakukan oleh. Irwanto dkk. (2016) mengungkapkan hal yang sama yaitu stres kerja berpengaruh negatif dan signifikan terhadap komitmen organisasional. Stres kerja berpengaruh negatif pada komitmen organisasi karena semakin tinggi stres mengakibatkan semakin menurunnya komitmen organisasi (Iresa et al, 2015). Penelitian yang dilakukan oleh Cha et al. (2016) dalam penelitiannya mengungkapkan stres kerja memiliki hubungan yang negatif dan signifikan dengan komitmen organisasional. Penelitian dari Harun et al. (2017) juga menunjukkan hasil yang sama yaitu stres kerja memiliki hubungan negatif yang signifikan dengan komitmen organisasional. Jadi, jika stres kerja yang dirasakan karyawan tinggi, maka akan membuat komitmen organisasional karyawan tersebut menjadi rendah. Maka dari itu hipotesis kedua dari penelitian ini adalah:

$\mathrm{H}_{2}$ : Stres Kerja berpengaruh negatif dan signifikan terhadap Komitmen Organisasional.

Komitmen organisasional memiliki pengaruh negatif terhadap turnover intention. Yang dimana jika seorang karyawan memiliki tingkat komitmen organisasional yang tinggi maka karyawan tersebut tidak akan berpikir untuk keluar dari organisasi atau perusahaan.

Thakre (2015) yang meneliti mengenai hubungan komitmen organisasional terhadap turnover intention menemukan bahwa adanya hubungan negatif antara turnover intention dengan komitmen organisasional, dimana terdapat indikasi turnover intention yang tinggi menandakan komitmen yang rendah. Kalidass dan Bahron (2015) juga menyatakan bahwa komitmen organisasional berhubungan negatif terhadap turnover intention. Susilo dan Satrya (2019) menyatakan bahwa komitmen organisasional berpengaruh negatif dan signifikan terhadap turnover intention. Youcef et al. (2016) memperlihatkan komitmen organisasional memiliki perngaruh yang negatif dan signifikan terhadap turnover intention. Semakin tinggi komitmen organisasional, maka keinginan keluar akan semakin turun. Bhatti et al. (2016) menyatakan bahwa terdapat pengaruh negatif antara komitmen organisasional terhadap turnover intention. Abdurrahim dkk. (2017) menyatakan bahwa komitmen organisasional berpengaruh negatif terhadap turnover intention. Dengan kata lain, semakin tinggi komitmen organisasional dari karyawan maka semakin rendah tingkat keinginan karyawan untuk keluar dari perusahaan. Maka dari itu hipotesis ketiga dari penelitian ini adalah:

$\mathrm{H}_{3}$ : Komitmen Organisasional berpengaruh negatif dan signifikan terhadap

Turnover Intention.

Pengaruh stres kerja terhadap turnover intention bersifat positif, yang dimana hal ini megisyaratkan dengan semakin tingi stres kerja yang dirasakan karyawan, maka akan semakin menurunkan tingkat komitmen organisasional 
karyawan. Dalam penelitiannya, Irwanto dkk. (2016) menyatakan bahwa komitmen organisasional adalah yang memediasi diantara stres kerja terhadap turnover intention. Putra dan Ardana (2018) komitmen organisasional terbukti memediasi pengaruh antara stres kerja dengan turnover intention secara parsial. Menurut Pranata dan Netra (2019) komitmen organisasional mampu memediasi pengaruh stres kerja terhadap turnover intention. Berdasarkan penelitian yang dilakukan sebelumnya, maka bisa didapatkan hipotesis sebagai berikut:

$\mathrm{H}_{4}$ : Komitmen Organisasional mampu memediasi pengaruh Stres Kerja terhadap Turnover Intention.

Salah satu teori yang digunakan dalam penelitian ini adalah traditional turnover theory. Traditional turnover theory mengamati turnover sebagai variabel utama yang kemudian memunculkan komitmen organisasi dan kepuasan kerja sebagai faktor yang dapat memprediksi perilaku turnover karyawan Zhao dan Liu dalam Rarasanti dan Suana (2016). Teori ini menyatakan hubungan negatif diantara komitmen orgaisasi dan turnover intention karyawan. Semakin tinggi komitmen organisasi karyawan akan menekan keinginan karyawan untuk meninggalkan perusahaan.

Turnover intention merupakan keinginan seseorang untuk berpindah, belum sampai pada tahap realisasi yaitu melakukan perpindahan dari satu tempat kerja ke tempat kerja lainnya (Putra dan Rahyuda, 2016). Firdaus (2017) turnover intention adalah keinginan untuk berpindah, belum sampai pada tahap realisasi yaitu melakukan perpindahan dari satu tempat kerja ke tempat kerja lainnya.

Turnover Intention timbul dari niat yang mengacu pada aktivitas karyawan untuk meninggalkan perusahaan dan mencari alternatif pekerjaan yang lain (Faslah dan Hairiah, 2017). Ksama dan Wibawa (2016) turnover intention merupakan masalah yang sering timbul pada sebuah organisasi yang menyangkut keinginan keluarnya karyawan dalam sebuah organisasi.

Rekha dan Paramanandam (2017) menyatakan bahwa stres adalah suatu kondisi yang terjadi ketika seseorang menyadari tekanan pada diri mereka atau tuntutan situasi yang berada di luar kendali mereka dan jika tuntutan ini terlalu tinggi dan berlanjut dengan jangka waktu yang lama tanpa interval, maka dapat menyebabkan gangguan mental, fisik atau perilaku pada individu tersebut. Syahronica dkk. (2015) menyatakan bahwa stres kerja merupakan suatu keadaan yang mempengaruhi emosi, proses berpikir, dan kondisi seseorang seperti kondisi tegang. Beloor et al. (2017) menyatakan bahwa pekerjaan harus dipelihara secara efektif untuk memastikan bahwa semua karyawan bekerja pada potensinya masing-masing dan bebas dari stres.

Stres kerja yang dialami oleh karyawan dapat menimbulkan dampak positif, sekaligus dampak negatif bagi yang bersangkutan dan bagi organisasi atau perusahaan. Aspek positif dari stres kerja itu dapat ditemukan jika dilihat dari kegunaannya dan kesediaan kita dalam menggunakannya. Dari beberapa penjelasan bahwa stres kerja dapat dikemukakan sebagai suatu keadaan tegang yang dialami seseorang didalam suatu organisasi.

Menurut Jamadin et al. (2015) menyatakan bahwa ketidakmampuan seeorang untuk mengatasi suatu tekanan dalm pekerjaannya dapat dikatakan sebagai stres. Dari pendapat dari beberapa ahli dapat disimpulkan bahwa stress 
kerja merupakan situasi di mana karyawan merasa tertekan akibat dari pekerjaan ataupun lingkungan di dalam organisasi. Chia-Hao dan Ting-Ya (2018) menyatakan bahwa stres kerja adalah keadaan seseorang yang terkena dampak tuntutan, ancaman, pembatasan dan peluang lingkungan kerja, menghasilkan persepsi subjektif dengan pengaruh karakteristik pribadi atau proses mental, dan setelah membandingkan persepsi subjektif dan karakteristik pribadi tersebut, ketidaksetaraan terjadi dan menyebabkan keadaan fisik, mental dan stabilitas individu menjadi terganggu.

\section{METODE PENELITIAN}

Penelitian ini dilakukan pada PT. BPR Pedungan yang beralamat di Jl. Pulau Moyo Nomor 1 Pesanggaran, Denpasar, Bali, Indonesia. PTPopulasi pada penelitian ini adalah 87 orang karyawan termasuk atasan yang ada pada PT. BPR Pedungan. Metode penentuan sampel yang digunakan dalam penelitian ini adalah sampel jenuh (sensus).

Tabel 3.

Data Jabatan, Jumlah dan Status Karyawan PT. BPR Pedungan

\begin{tabular}{lccc}
\hline \multicolumn{1}{c}{ Jabatan } & Populasi & \multicolumn{2}{c}{ Status } \\
Karyawan tetap & Karyawan Kontrak \\
\hline Staf Kantor Kas & 4 & 4 & - \\
Personalia & 2 & 1 & - \\
Pembinaan Kredit & 3 & 3 & 2 \\
Pemasaran Kredit & 3 & 1 & - \\
Analisa Kredit & 1 & 1 & 2 \\
Admin Kredit & 4 & 2 & - \\
Angsuran Kredit & 1 & 1 & - \\
Akunting & 1 & 1 & - \\
Operator & 1 & 1 & 2 \\
IT & 1 & 1 & 1 \\
Customer Service & 3 & 2 & 2 \\
Kasir & 3 & 17 & - \\
Kolektor Tabungan & 30 & 4 & 1 \\
Satpam & 6 & 3 & 2 \\
Waker & 3 & 4 & 26 \\
OB & 5 & 2 & \\
Sopir & 4 & 49 & \\
Total & 75 & & \\
\hline
\end{tabular}

Sumber: PT. BPR Pedungan, 2019

Penelitian ini menggunakan teknik analisis jalur atau path analysis. Analisis jalur (path analysis) adalah perluasan dari analisis regresi linier berganda. Persamaan model berdasarkan teknik analisis ini yaitu:

Persamaan Sub-struktural 1

$\mathrm{M}=\beta_{1} \mathrm{X}_{1}+\mathrm{e}_{1}$

Persamaan Sub-struktural 2

$\mathrm{Y}=\beta_{2} \mathrm{X}_{2}+\beta_{3} \mathrm{M}+\mathrm{e}_{2}$

Keterangan:

$\mathrm{X} \quad=$ stres kerja 


$\begin{array}{ll}\mathrm{M} & =\text { komitmen organisasional } \\ \mathrm{Y} & =\text { turnover intention } \\ \beta_{1-} \beta_{2} & =\text { Koefisien regresi variabel } \\ \mathrm{e} & =\text { error }\end{array}$

\section{HASIL DAN PENELIATIAN}

Data karakteristik responden adalah data responden yang dikumpulkan untuk mengetahui profil responden penelitian. Berdasarkan hasil penelitian yang dilakukan terhadap karyawan di PT BPR Pedungan dapat diketahui karakteristik respondennya meliputi, jenis kelamin, umur, dan pendidikan terakhir yang dijelaskan pada Tabel 4.

Tabel 4.

Karakteristik Responden

\begin{tabular}{|c|c|c|c|c|}
\hline No. & Variabel & Klasifikasi & Jumlah & Persentase \\
\hline \multirow[t]{3}{*}{1.} & Jenis Kelamin & Laki-laki & 50 & 70,42 \\
\hline & & Perempuan & 21 & 29,8 \\
\hline & & Jumlah & 71 & 100 \\
\hline \multirow[t]{5}{*}{2.} & Usia & $<21$ Tahun & 16 & 22,54 \\
\hline & & 21-30 Tahun & 25 & 35,21 \\
\hline & & 31-40 Tahun & 7 & 9,86 \\
\hline & & $>40$ Tahun & 23 & 32.39 \\
\hline & & Jumlah & 71 & 100 \\
\hline \multirow[t]{7}{*}{3.} & Tingkat Pendidikan & SD & 0 & 0 \\
\hline & & SMP & 1 & 1,41 \\
\hline & & SMA & 53 & 24,65 \\
\hline & & DIPLOMA & 0 & 0 \\
\hline & & $\mathrm{S} 1$ & 17 & 23,94 \\
\hline & & $\mathrm{S} 2$ & 0 & 0 \\
\hline & & Jumlah & 71 & 100 \\
\hline \multirow[t]{5}{*}{4.} & Masa Kerja & $<3$ Tahun & 39 & 54,93 \\
\hline & & 3-5 Tahun & 5 & 7,04 \\
\hline & & 6-15 Tahun & 6 & 8,45 \\
\hline & & $>15$ & 21 & 29,58 \\
\hline & & Jumlah & 71 & 100 \\
\hline
\end{tabular}

Sumber: Data diolah, 2019

Berdasarkan Tabel 4. dapat di lihat jumlah karyawan di PT BPR Pedungan yang di jadikan sampel sebanyak 71 orang. Jika dilihat dari jenis kelamin, jenis kelamin laki-laki mendominasi dalam penelitian ini dengan persentase sebesar 70,42 persen. Jika di lihat dari usia, yang memiliki usia 21,30 tahun mendominasi dengan persentase sebesar 35,21 persen. Hal ini dikarenakan pada usia tersebut seseorang masih berada pada usia produktif. Jika di lihat dari tingkat pendidikan yang memiliki tingkat pendiddikan terakhir SMA yang mendominasi dengan persentase sebesar 56,67 persen. Jika dilihat dari masa kerja masa kerja $>3$ tahun mendominasi dengan persentase 39 persen. 
Pada penelitian ini dihitung pengaruh stres kerja terhadap komitmen organisasional melalui program SPSS 21.0 for windows. Berikut ini ditampilkan hasil perhitungan struktur pertama pada Tabel 5.

Tabel 5.

Hasil Analisis Jalur Pada Struktur 1

\begin{tabular}{llccccc}
\hline & Model & \multicolumn{2}{c}{$\begin{array}{c}\text { Unstandardized } \\
\text { Coefficients }\end{array}$} & $\begin{array}{c}\text { Standardized } \\
\text { Coefficients } \\
\text { Beta }\end{array}$ & t & Sig \\
& B & Std. Error & Beta & & \\
\hline \multirow{2}{*}{$\begin{array}{l}\text { (Constant) } \\
\text { Stres Kerja }\end{array}$} & 4,356 & 0,273 & & 15,955 & 0,000 \\
$\mathrm{R}^{2}=0,100$ & $-0,417$ & 0,150 & $-0,317$ & $-2,772$ & 0,007 \\
\hline \multicolumn{2}{l}{ Sumber :Data diolah, 2020} \\
\end{tabular}

Berdasarkan hasil analisis jalur pada Tabel 5 maka dapat dirumuskan persamaan struktural yang terbentuk adalah sebagai berikut.

$$
\begin{gathered}
M=\beta 1 X+\mathrm{e} 1 \\
M=-0,317 \mathrm{X}+\mathrm{e} 1
\end{gathered}
$$

Persamaan struktural tersebut dapat diartikan yaitu variabel stres kerja memiliki koefisien sebesar -0,317 yang berarti stres kerja memiliki pengaruh negatif terhadap komitmen organisasional, ini diartikan apabila stres kerja meningkat maka komitmen organisasional akan menurun sebesar 0,317.

Pada penelitian ini dihitung pengaruh stres keja dan komitmen organisasional terhadap turnover intention melalui program SPSS 21.0 for windows. Berikut ini ditampilkan hasil perhitungan struktur kedua pada Tabel 6.

Tabel 6.

\begin{tabular}{|c|c|c|c|c|c|}
\hline \multirow[t]{2}{*}{ Model } & \multicolumn{2}{|c|}{$\begin{array}{l}\text { Unstandardized } \\
\text { Coefficients }\end{array}$} & \multirow{2}{*}{$\begin{array}{c}\text { Standardized } \\
\text { Coefficients } \\
\text { Beta } \\
\end{array}$} & \multirow[t]{2}{*}{$\mathbf{T}$} & \multirow[t]{2}{*}{ Sig } \\
\hline & B & Std. Error & & & \\
\hline (Constant) & 1,390 & 0,360 & & 3,862 & 0,000 \\
\hline I Stres Kerja & 1,089 & 0,097 & 0,731 & 11,281 & 0,000 \\
\hline $\begin{aligned} & \text { Komitmen } \\
& \text { Organisasional } \\
\mathrm{R}^{2}= & 0,743\end{aligned}$ & $-0,318$ & 0,073 & $-0,281$ & $-4,335$ & 0,000 \\
\hline
\end{tabular}

Hasil Analisis Jalur Pada Struktur 2

Berdasarkan hasil analisis jalur pada Tabel 6 maka dapat dirumuskan persamaan struktural yang terbentuk adalah sebagai berikut.

$$
\begin{gathered}
\mathrm{Y}=\beta 2 \mathrm{X}+\beta 3 \mathrm{M}+\mathrm{e} 2 \\
\mathrm{Y}=0,731 \mathrm{X}+-0,281 \mathrm{M}+\mathrm{e} 2
\end{gathered}
$$

Persamaan structural tersebut dapat diartikan yaitu variabel stres kerja memiliki koefisien sebesar 0,731 berarti stres kerja memiliki pengaruh positif terhadap turnover intention, ini diartikan apabila stres kerja meningkat maka turnover intention akan meningkat sebesar 0,731. Variabel komitmen organisasional memiliki koefisien sebesar -0,281 berarti komitmen organisasional memiliki pengaruh negatif terhadap turnover intention, ini diartikan apabila 
komitmen organisasional meningkat maka turnover intention akan menurun sebesar $-0,281$.

Pada pengujian ini akan dilihat nilai masing-masing koefisien determinasi untuk struktur 1 dan struktur 2 serta nilai masing-masing variabel error pada setiap struktur dengan tujuan penyusunan model diagram jalur akhir. Berikut ini hasil perhitungan nilai variabel error pada setiap struktur.

$$
\begin{aligned}
& \mathrm{e}_{\mathrm{i}}=\sqrt{1-R_{i}^{2}} \\
& \mathrm{e}_{1}=\sqrt{1-R_{1}^{2}}=\sqrt{1-0,100}=0,948 \\
& \mathrm{e}_{2}=\sqrt{1-R_{2}^{2}}=\sqrt{1-0,743}=0,506 \\
& \mathrm{R}^{2} \mathrm{~m}=1-(\mathrm{e} 1)^{2}(\mathrm{e} 2)^{2} \\
& =1-(0,948)^{2}(0,506)^{2} \\
& =1-(0,898)(0,256) \\
& =1-0,229=0,770
\end{aligned}
$$

Pada perhitungan nilai koefisien determinasi total didapatkan sebesar 0,770 , maka kesimpulannya adalah $77,7 \%$ variabel turnover intention pada karyawan di PT BPR Pedungan dipengaruhi oleh stres kerja dan komitmen organisasional, sedangkan sisanya $22,3 \%$ dipengaruhi oleh faktor lain yang tidak dimasukkan dalam model penelitian atau diluar model penelitian.

Berdasarkan hasil pada Tabel 5. stres kerja memiliki nilai Beta sebesar 0,317 dan nilai Sig. sebesar 0,007, maka dapat dikatakan H1 diterima karena nilai Sig. $0,007<0,05$. Kesimpulannya adalah bahwa stres kerja memiliki pengaruh negatif dan signifikan terhadap komitmen organisasional, dengan kata lain semakin meningkat stres kerja pada karyawan di PT BPR Pedungan Denpasar, maka semakin menurun komitmen organisasional pada karyawan di PT BPR Pedungan, sehingga hipotesis pertama diterima.

Berdasarkan hasil pada Tabel 6. stres kerja memiliki nilai Beta sebesar 0,731 dan nilai Sig. sebesar 0,000, maka dapat dikatakan $\mathrm{H} 2$ diterima karena nilai Sig. $0,000<0,05$. Kesimpulannya adalah stres kerja berpengaruh positif dan signifikan terhadap turnover intentionn dengan kata lain semakin meningkat stres kerja pada PT. BPR Pedungan maka turnover intention pada karyawan di PT. BPR Pedungan akan semakin meningkat. Sehingga hipotesis kedua diterima.

Berdasarkan hasil pada Tabel 6. komitmen organisasional memiliki nilai Beta sebesar -0,281 dan nilai Sig. sebesar 0,000, maka dapat dikatakan H3 diterima karena nilai Sig. 0,000 <0,05. Kesimpulannya adalah bahwa komitmen organisasional memiliki pengaruh negatif dan signifikan terhadap turnover intention, dengan kata lain apabila komitmen organisasional pada PT BPR Pedungan meningkat maka turnover intention karyawan di PT BPR Pedungan akan semakin menurun. Sehingga hipotesis ketiga diterima.

Pada langkah terakhir ini akan dijelaskan hasil nilai dari perhitungan koefisien jalur yang ditunjukkan melalui nilai standardized coefficient Beta pada masing-masing pengaruh hubungan antar variabel.

pengaruh total dari masing-masing persamaan struktural yang akan disajikan dalam Tabel 7. berikut ini. 
Tabel 7.

Pengaruh Langsung, Pengaruh Tidak Langsung Stres Kerja (X), Terhadap Komitmen Organisasional (M) dan Turnover Intention (Y).

\begin{tabular}{cccc}
\hline Pengaruh Variabel & $\begin{array}{c}\text { Pengaruh } \\
\text { Langsung }\end{array}$ & $\begin{array}{c}\text { Pengaruh Tidak } \\
\text { Langsung Melalui M }\end{array}$ & Pengaruh Total \\
\hline X-M & $-0,317$ & & $-0,317$ \\
M-Y & $-0,281$ & & $-0,281$ \\
X-Y & 0,731 & 0,089 & 0,820 \\
\hline Sumber Data diolah 2020 & & &
\end{tabular}

Pada penelitian yang dilakukan pada karyawan di PT BPR Pedungan tentang pengaruh stres kerja terhadap komitmen organisasional, maka didapatkan hasil stres kerja memiliki pengaruh langsung terhadap komitmen organisasional sebesar $-0,317$ atau $-31,7 \%$.

Pada penelitian yang dilakukan pada karyawan di PT BPR Pedungan tentang pengaruh komitmen organisasional terhadap turnover intention, maka didapatkan hasil komitmen organisasional memiliki pengaruh langsung terhadap turnover intention sebesar 0,731 atau 73,1\%.

Pada penelitian yang dilakukan pada karyawan di PT BPR Pedungan tentang pengaruh komitmen organisasional terhadap turnover intention, maka didapatkan hasil komitmen organisasional memiliki pengaruh langsung terhadap turnover intention sebesar $-0,281$ atau $-28,1 \%$.

Pada penelitian yang dilakukan pada karyawan di PT BPR Pedungan tentang peran komitmen organisasional dalam memediasi pengaruh stres kerja terhadap turnover intention, maka didapatkan hasil bahwa stres kerja memiliki pengaruh langsung dan tidak langsung melalui komitmen organisasional terhadap turnover intention dengan nilai koefisien masing-masing sebesar 0,731 dan 0,089, sehingga besaran pengaruh totalnya adalah 0,820 atau $82 \%$.

Uji sobel merupakan alat analisis untuk menguji signifikansi dari hubungan tidak langsung antara variabel independen dengan variabel dependen yang dimediasi oleh variabel mediator. Uji Sobel dirumuskan dengan persamaan berikut dan dapat dihitung dengan menggunakan aplikasi Microsoft Excel 2010. Bila nilai kalkulasi Z lebih besar dari 1,96 (dengan tingkat kepercayaan 95 persen), maka variabel mediator dinilai secara signifikan memediasi hubungan antara variabel terikat dan variabel bebas.

Pengujian pengaruh tidak langsung variabel stress kerja (X) terhadap turnover intention $(\mathrm{Y})$ melalui variabel komitmen organisasional $(\mathrm{M})$, dilakukan dengan $\mathrm{z}$ hitung $\leq 1,96$ maka H0 diterima yang berarti M bukan variabel mediasi.

$Z=\frac{\mathrm{ab}}{\sqrt{\left(\mathrm{b}^{2} \mathrm{Sa}^{2}\right)+\left(\mathrm{a}^{2} \mathrm{Sb}^{2}\right)+\left(\mathrm{Sa}^{2} \mathrm{Sb}^{2}\right)}}$

Keterangan:

$\begin{array}{ll}\mathrm{a} & =-0,317 \\ \mathrm{Sa} & =0,150 \\ \mathrm{~b} & =-0,281 \\ \mathrm{Sb} & =0,073\end{array}$




$$
\begin{gathered}
Z=\frac{-0,317 .-0,281}{\sqrt{\left(-0,281^{2} 0,150^{2}\right)+\left(-0,317^{2} 0,073^{2}\right)+\left(0,150^{2} 0,073^{2}\right)}} \\
Z=\frac{0,089}{0,027} \\
Z=3,29
\end{gathered}
$$

Berdasarkan hasil Uji Sobel menunjukkan bahwa hasil tabulasi $Z=3,29>$ 1,96 yang berarti variabel stres kerja berpengaruh positif dan signifikan terhadap turnover intention pada karyawan di PT BPR Pedungan dengan mediasi komitmen organisasional, sehingga komitmen organisasional merupakan variabel mediasi pengaruh antara stres kerja terhadap turnover intention pada karyawan di PT BPR Pedungan, sehingga hipotesis keempat diterima.

Hasil hipotesis dalam penelitian ini menunjukkan bahwa stres kerja memiliki pengaruh positif dan signifikan terhadap turnover intention, dengan kata lain semakin meningkat stres kerja pada karyawan di PT. BPR Pedungan, maka semakin tinggi tingkat turnover intention pada karyawan di PT. BPR Pedungan. Sehingga hipotesis kedua diterima.

Hasil penelitian ini sejalan dengan penelitian Yuda dan Ardana (2017) menyebutkan bahwa stres kerja memiliki pengaruh positif terhadap turnover intention. Penelitian Siddiqui dan Jamil (2015) menunjukkan bahwa terdapat hubungan positif dan langsung antara stres kerja dan turnover intention, sehingga peningkatan stres kerja akan meningkatkan pula keinginan berpindah kerja.

Sewandi dan Perere (2016) menyatakan bahwa stres kerja berpengaruh positif terhadap turnover intention. Nasution (2017) juga mengungkapkan bahwa stres kerja memiliki pengaruh signifikan dan positif pada turnover intention. Ketabchi dan Hazraty (2015) juga membuktikan bahwa stres kerja mempunyai pengaruh positif terhadap turnover intention. Pengaruh yang positif mengindikasikan dengan semakin tingginya stres kerja yang dirasakan karyawan, maka semakin meningkatkan kecenderungan karyawan untuk melakukan turnover.

Hasil hipotesis dalam penelitian ini menunjukkan bahwa stres kerja memiliki pengaruh negatif dan signifikan terhadap komitmen organisasional, dengan kata lain semakin meningkat stres kerja pada karyawan di PT. BPR Pedungan, maka semakin turun tingkat komitmen organisasional pada karyawan di PT. BPR Pedungan. Sehingga hipotesis pertama diterima.

Hasil penelitian ini sejalan dengan penelitian Irwanto dkk. (2016) mengungkapkan hal yang sama yaitu stress kerja berpengaruh negatif dan signifikan terhadap komitmen organisasional. Stres kerja berpengaruh negatif pada komitmen organisasional karena semakin tinggi stres mengakibatkan semakin menurunnya komitmen organisasi (Iresa dkk., 2015). Penelitian yang dilakukan oleh (Cha et al., 2016) dalam penelitiannya mengungkapkan stres kerja memiliki hubungan yang negatif dan signifikan dengan komitmen organisasional. Penelitiandari Harun et al. (2017) juga menunjukkan hasil yang sama yaitu stres kerja memiliki hubungan negatif yang signifikan dengan komitmen organisasional. Jadi, jika stres kerja yang dirasakan karyawan tinggi, maka akan membuat komitmen organisasional karyawan tersebut menjadi rendah.

Hasil hipotesis dalam penelitian ini menunjukkan bahwa komitmen organisasional memiliki pengaruh negatif dan signifikan terhadap turnover 
intention, dengan kata lain semakin meningkat komitmen organisasional pada karyawan di PT. BPR Pedungan, maka semakin turun tingkat turnover intention pada karyawan di PT. BPR Pedungan. Sehingga hipotesis ketiga diterima.

Hasil penelitian ini sejalan dengan penelitian Thakre (2015) yang meneliti mengenai hubungan komitmen organisasional terhadap turnover intention menemukan bahwa adanya hubungan negatif antara turnover intention dengan komitmen organisasional, dimana terdapat indikasi turnover intention yang tinggi menandakan komitmen yang rendah. Kalidass dan Bahron (2015) juga menyatakan bahwa komitmen organisasional berhubungan negatif terhadap turnover intention. Susilo dan Satrya (2019) menyatakan bahwa komitmen organisasional berpengaruh negatif dan signifikan terhadap turnover intention. Youcef et al. (2016) memperlihatkan komitmen organisasional memiliki perngaruh yang negatif dan signifikan terhadap turnover intention. Semakin tinggi komitmen organisasional, maka keinginan keluar akan semakin turun. Bhatti et al. (2016) menyatakan bahwa terdapat pengaruh negatif antara komitmen organisasional terhadap turnover intention. Abdurrahim dkk. (2017) menyatakan bahwa komitmen organisasional berpengaruh negatif terhadap turnover intention. Dengan kata lain, semakin tinggi komitmen organisasional dari karyawan maka semakin rendah tingkat keinginan karyawan untuk keluar dari perusahaan.

Hasil hipotesis dalam penelitian ini menunjukkan stres kerja berpengaruh positif dan signifikan terhadap turnover intention pada karyawan di PT. BPR Pedungan dengan mediasi komitmen organisasional, sehingga komitmen organisasional merupakan variabel mediasi pengaruh antara stres kerja terhadap turnover intention pada karyawan di PT BPR Pedungan, sehingga hipotesis keempat diterima.

Hasil penelitian ini sejalan dengan penelitian Rismawan dkk. (2015) membuktikan bahwa stres kerja berpengaruh terhadap turnover intention dimediasi oleh komitmen organisasional. Irwanto dkk. (2016) menyatakan bahwa komitmen organisasional adalah yang memediasi diantara stres kerja terhadap turnover intention. Putra dan Ardana (2018) komitmen organisasional terbukti memediasi pengaruh antara stres kerja dengan turnover intention secara parsial. Menurut Pranata dan Netra (2019) komitmen organisasional mampu memediasi pengaruh stres kerja terhadap turnover intention.

Implikasi teoritis dari hasil penelitian ini memberikan bukti pada pengembangan ilmu perilaku keorganisasian dan sumber daya manusia khususnya mengenai stres kerja, komitmen organisasional dan turnover intention. Selain itu hasil penelitian ini secara praktis dapat menjadi salah satu acuan bagi peneliti lainnnya yang ingin meneliti mengenai stres kerja, komitmen organisasional dan turnover intention. Secara teoritis penelitian ini juga memberikan pemahaman bahwa stres kerja dan komitmen organisasional secara nyata dapat meningkatkan turnover intention, ketika stres kerja yang diperoleh oleh karyawan menurunkan komitmen organisasional, maka komitmen organisasional yang dirasakan oleh karyawan menjadi semakin kuat sehingga berpotensi meningkatkan turnover intention.

Berdasarkan penelitian yang telah dilakukan, terdapat beberapa keterbatasan dalam penelitian ini, yaitu penelitian ini dilakukan hanya sebatas pada ruang 
lingkup PT. BPR Pedungan sehingga hasil penelitian ini tidak dapat digunakan pada perusahaan lain dalam perbankan atau lembaga keuangan lainnya. Faktorfaktor yang mempengaruhi turnover intention dalam penelitian ini adalah stress kerja dan komitmen organisasional, sedangkan masih banyak faktor lain yang dapat mempengaruhi.

\section{SIMPULAN}

Stres kerja berpengaruh positif dan signifikan terhadap turnover intention di PT. BPR Pedungan, sehingga hipotesis 1 diterima. Stres kerja berpengaruh negatif dan signifikan terhadap komitmen organisasional di PT. BPR Pedungan, sehingga hipotesis 2 diterima. Komitmen organisasional berpengaruh negatif dan signifikan terhadap turnover intention di PT. BPR Pedungan, sehingga hipotesis 3 diterima. Komitmen organisasional merupakan variabel mediasi pengaruh antara stres kerja terhadap turnover intention di PT. BPR Pedungan, sehingga hipotesis 4 diterima.

Berdasarkan hasil yang diperoleh stres kerja memiliki pengaruh yang positif signifikan terhadap turnover intention pada karyawan di PT. BPR Pedungan, ini menunjukan bahwa semakin tinggi stres kerja akan dapat meningkatkan turnover intention pada karyawan di PT. BPR Pedungan. PT. BPR Pedungan harus bisa menurunkan stres kerja di dalam perusahaan agar karyawan mengurungkan niat untuk meninggalkan perusahaan. Komitmen organisasional memiliki pengaruh negatif dan signifikan terhadap turnover intention pada karyawan di PT. BPR Pedungan oleh karena ini PT BPR Pedungan harus bisa meningkatkan komitmen organisasional yaitu dengan mengurangi tuntutan kerja karyawan dan meningkatkan kemampuan karyawan agar menurunkan turnover intention.

Dari segi stres kerja indikator yang memiliki rata-rata terendah adalah "Saya ingin menyerah apabila saya frustasi saat pekerjaan yang saya kerjakan tidak sesuai dengan harapan", yang harus dilakukan oleh PT. BPR Pedungan adalah PT. BPR Pedungan harus memberikan motivasi dan support agar karyawan tidak merasa frustasi pada saat melakukan pekerjaan. Dari segi komitmen organisasional indikator yang memiliki rata-rata terendah adalah "Saya akan merasa terganggu bila meninggalkan organisasi ini", hal yang harus dilakukan oleh karyawan PT. BPR Pedungan adalah Mereka harus semangat dan menumbuhkan rasa nyaman dalam bekerja agar tidak keluar dari perusahaan.

Bagi penelitian selanjutnya diharapkan mampu menambah variabel-variabel yang dapat mempengaruhi turnover intention, serta mampu untuk memperluas ruang lingkup penelitian yang tidak hanya terbatas pada karyawan di PT. BPR Pedungan, atau dapat juga mengganti lokasi penelitian yang tidak hanya terfokus pada suatu lokasi penelitian, sehingga memberikan suatu pandangan yang lebih dan mampu diimplementasikan secara umum.

\section{REFERENSI}

Abdurrahim, Anisah, H. U., \& Dewi, M. S. (2017). Pengaruh Kepuasan Kerja dan Komitmen Organisasi. Jurnal Ilmiah Manajemen, 1(2), 1-11.

Ariansyah. (2019). Pengaruh Job Insecurity, Stres Kerja, dan Kepuasan

Kompensasi Terhadap Intention To Quit Karyawan PT. Mandala Finance 
Tbk Cabang IDI. Jurnal Manajemen Dan Akuntansi, 5(1), 22-30.

Azeez, R. O., Jayeoba, F. I., \& Adeoye, A. O. (2016). Job Satisfaction, Turnover Intention and Organizational Commitment. Journal of Management Research, 8(2), 102-114.

Beloor, V., Nanjundeswaraswamy, T. S., \& Swamy, D. R. (2017). Employee Commitment and Quality of Work Life-a Literature Review. The International Journal of Indian Psychology, 4(2), 175-188.

Bhatti, M. H., Bhatti, M. H., Akram, U., Bilal, M., \& Akram, Z. (2016). Impact of Organization Commitment on Turnover Intention : Mediating Role of Job Contentment. European Journal of Business and Management, 8(13), 24-39.

Bramantara, B., \& Dewi, K. (2015). Pengaruh Kepuasan Kerja dan Komitmen Organisasi Terhadap Turnover Intention Karyawan Pada Krisna Oleh - Oleh Khas Bali III. Jurnal Ilmu Manajemen, 6(10), 1-20.

Cha, J. L. M., Kim, S. H., \& Cichy, R. F. (2016). Job Satisfaction, Organizational Commitment, and Contextual Performance : Examining Effects of Work Status and Emotional Intelligence among Private Club Staff Members. Psychology and Marketing, 21(6), 405-424.

Chia-Hao, C., \& Ting-Ya, H. (2018). The Study of Employee's Job Stress, Happiness and Job Performance - Taiwan Construction Industry Company for Example. The International Journal of Organizational Innovation, 10(3), $126-143$.

Faslah, R., \& Hairiah, L. (2017). The Influence of Job Involement and Job Satisfaction Toward Turnover Intention on Employees of PT. Global Nikel Multiguna Tangerang. Jurnal Ilmiah Econosains, 15(1), 140165.

Firdaus, A. (2017). Faktor-Faktor Yang Mempengaruhi Turnover Intention (Studi Pada Karyawan Perusahaan Jasa Multi Finance Di Kota Jambi). Jurnal of Economics and Business, 1(1), 1-10.

Harun, H., Salleh, R., Memon, M. A., Baharom, M. N. R., \& Abdullah, A. (2017). Job Satisfaction, Organizational Commitment and Stress among Offshore Oil and Gas Platform Employees. Asian Social Science, 10(11), 28-32. Retrieved from https://doi.org/10.5539/ass.v10n11p28\%0A\%0A

Iresa, A. R., Utami, H. N., \& Prasetya, A. (2015). Pengaruh Konflik Kerja dan Stres Kerja terhadap Komitmen Organisasional dan Kinerja Karyawan (studi pada Karyawan PT. Telekomunikasi Indonesia, tbk Witel Malang). Jurnal Administrasi Bisnis (JAB), 23(1), 1-10.

Irwanto, Riana, I. G., \& Yasa, N. N. K. (2016). Peran Komitmen Organisasional Memediasi Pengaruh Stres Kerja Dan Kepuasan Kerja Terhadap Intensi Keluar. E-Jurnal Ekonomi Dan Bisnis Universitas Udayana, 5(9), 28912910. 
Jamadin, N., Samsiah, M., Syarkawi., Zurwita., \& Fauziah, N. (2015). Work Family-Conflict and Stress: Evidence From Malaysia. Journal of Economics, Business and Management, 3(2), 309-312.

Kalidass, A., \& Bahron, A. (2015). The Relationship between Perceived Supervisor Support, Perceived Organizational Support, Organizational Commitmen and Employee Turnover Intention. International Journal of Business Administration, 6(5), 82-89.

Ketabchi, H., \& Hazraty, M. (2015). Examining the Relationship between Job Stress and Turnover Tendency with Mediating Role of Job Satisfaction among the Employees of Alzahra Hospital in Rasht. Jurnal UMP Social Sciences and Technology Management, 3(3), 842-846.

Ksama, I. B. P. T., \& Wibawa, I. M. A. (2016). Pengaruh Leader-MemberExchange, Role Stress dan Perceived Organizational Support Terhadap Turnover Intention. E-Jurnal Manajemen Unud, 5(10), 6174-6200. Retrieved from https://ojs.unud.ac.id/index.php/Manajemen/article/view/21245/15738

Lestari, N. N. Y. S., \& Mujiati, N. W. (2018). Pengaruh Stres Kerja, Komitmen Organisasi, Dan Kepuasan Kerja Karyawan Terhadap Turnover Intention. EJurnal Manajemen Unud, 7(6), 3412-3441.

Mary, M. (2016). Impact of Employee Training and Motivation on Business Development in Banking Sector: Study Conducted in Pakistan. American Journal of Business, Economics and Management, 7(9), 145-230.

Meriani, N. M. K., \& Sudibya, G. A. (2016). Pengaruh Kepemimpinan Transformasional Terhadap Komitmen Organisasional Dengan Mediasi Pemberdayaan Di PT. PLN (Persero) Rayon Denpasar. E-Jurnal Manajemen UnudUnud, 5(10), 6058-6087.

Nasution, M. I. (2017). Pengaruh Stres Kerja, Kepuasan Kerja Dan Komitmen Organisasi Terhadap Turnover Intention Medical Representative. Jurnal Ilmiah Manajemen, 7(3), 407-428.

Parvaiz, L., Saba, B., Ambar, K., \& Yasir, A. F. (2015). Impact of Stressors (Role Conflict, Role Overload, Leadership Support and Organizational Politics) on Job Stress and its Subsequent Impact on Turnover Intention. International Journal of Business and Management Invention, 4(10), 52-63.

Pranata, G. D., \& Netra, I. G. S. K. (2019). Pengaruh Stres Kerja Terhadap Turnover Intention Melalui Mediasi Komitmen Organisasional Pada Restoran Queen's Tandoor Seminyak. E-Jurnal Ekonomi Dan Bisnis Universitas Udayana, 8(6), 3531-3559.

Pristiwati, M., \& Sunuharyo, B. S. (2018). Pengaruh Komitmen Organisasional Dan Organizational Citizenship Behavior Terhadap Kinerja Karyawan (Studi Pada Karyawan PT PLN (Persero) Area Sidoarjo). Jurnal Administrasi 
Bisnis, 61(4), 159-168.

Putra, I. B. G. S., \& G., R. A. (2016). Pengaruh Kompensasi, Lingkungan Kerja Dan Perceived Organizational Support (POS) Terhadap Retensi Karyawan. E-Jurnal Manajemen Unud, 5(2), 810-837.

Putra, I. G. Y., \& Ardana, I. K. (2018). Peran Komitmen Organisasional Dalam Memediasi Pengaruh Stres Kerja Terhadap Turnover Intention Di Bali Rochmat Jaya. E-Jurnal Manajemen Unud, 5(12), 6562-6590.

Rarasanti, I. A. P., \& Suana, I. W. (2016). Pengaruh Job Embeddedness, Kepuasan Kerja, dan Komitmen Organisasional terhadap Turnover Intention Karyawan. E-Jurnal Manajemen UnudUnud, 5(7), 4690-4718.

Rekha, B., \& Paramanandam, P. (2017). Job Stress and Job Satisfaction Among the Managerial Personnel of Textile Industry. Sumedha Journal of Management, 6(3), 65-74.

Rismawan, P. A. E., Supartha, W. G., \& Yasa, N. N. K. (2015). Peran Mediasi Komitmen Organisasional pada Pengaruh Stres Kerja dan Kepuasan Kerja terhadap Intensi Keluar Karyawan. E-Jurnal Ekonomi Dan Bisnis Universitas Udayana, 8(3), 424-441.

Robbins, P. S., \& Judge, T. A. (2017). Organizational Behaviour Jilid 1 (13th ed.). Jakarta: Salemba Empat.

Sandi, Q., Syukri, A., \& Anwar, K. (2019). Manajemen Sumber Daya Manusia Dalam Meningkatkan Keunggulan Kompetitif. Jurnal Kajian Pendidikan Islam Dan Studi Islam, 2(2), 63-84.

Setiyanto, A. I., \& Hidayati, S. N. (2017). Pengaruh Kepuasan Kerja dan Komitmen Organisasi terhadap Turnover Intention. Jurnal Akuntansi, Ekonomi Dan ManajemenBisnis, 5(1), 105-110.

Sewandi, D. V., \& Perere, G. D. (2016). The Impact of Job Stress on Turnover Intention: A Study of Reputed Apparel Firm in Sri Lanka. 3rd International HRM Conference, 3(1), 223-229.

Siddiqui, A. A., \& Jamil, R. A. (2015). Antecedents of Employees Turnover Intentions: Evidence from Private Educational Institutions. American Journal of Economics and Business Administration, 7(4), 160-165.

Susilo, J., \& Satrya, I. G. B. H. (2019). Pengaruh Kepuasan Kerja Terhadap Turnover Intention yang Dimediasi oleh komitmen Organisasional Karyawan Kontrak. E-Jurnal Manajemen Unud, 8(6), 3700-3729.

Syahronica, G., Hakam, M. S., \& Ruhana, I. (2015). Pengaruh Kepuasan Kerja Dan Stress Kerja Terhadap Turnover Intention (Studi Pada Karyawan Departemen Dunia Fantasi PT. Pembangunan Jaya Ancol, Tbk). Jurnal Administrasi Bisnis (JAB), 20(1), 1-6.

Thakre, N. (2015). Organizational Commitment and Turnover Intention in 
Anak Agung Bagus Alit Sidi Mantra, Peran Komitmen Organisasional...

BPOITeS and Retail Sector Employees. Journal of Psychosocial Research, 10(1), 89-98.

Youcef, S., Ahmed, S. S., \& Ahmed, B. (2016). The Impact of Job Satisfaction on Turnover Intention by the Existence of Organizational Commitment, and Intent to Stay as Intermediates Variables Using approach PLS in Sample Worker Department of Transport Saida. Journal Management, 6(6), 198-202.

Yuda, I. B. D. P., \& Ardana, I. K. (2017). Pengaruh Kepuasan Kerja dan Stres Kerja terhadap Turnover Intention pada Karyawan Hotel Holiday Inn Express. E-Jurnal Manajemen Unud, 6(10), 5319-5347. 